\title{
"Slowly and Beyond the Duration of Love" HIV/AIDS i litteratur från södra Afrika
}

\section{Av Maria Olaussen}

\author{
Länk till presentation av Maria Olaussen
}

Det vi allra först får höra vid stora katastrofer är siffror: 40 miljoner i hela världen, 26 miljoner mänskor i södra Afrika, 30 procent av alla smittade, en person i minuten... Siffror ger en form av kunskap, men de skapar också ett sätt att se på just HIV/AIDSproblematiken som kan leda till att situationen förvärras.

Aktivister inom den sydafrikanska organisationen Treatment Action Campaign påpekar att en fokusering på statistik i form av antal HIV-positiva leder till ett sätt att tänka där siffrorna anger nederlag - redan förlorade mänskor. Den skapar en polarisering mellan prevention och behandling, där preventionen är det enda som verkligen kan ändra statistiken och ge resultat. Verkligheten i södra Afrika är en annan. Här lever personer med HIV som samtidigt har en viktig uppgift att fylla som familjemedlemmar, medborgare, arbetstagare. För att dessa personer ska få tillgång till bromsmediciner krävs ett politiskt nytänkande i regionen, en mera klarsynt attityd till problemets omfattning och till vad som verkligen kan göras. Detta gäller naturligtvis också på det individuella planet. Behandling kräver öppenhet och medvetenhet - den motverkar en av de största riskerna som nu finns, nämligen den att smittade personer helt förnekar sin sjukdom eller tvingas att ignorera den. Majoriteten av de smittade i södra Afrika har i dag inget val - de har inte tillgång till bromsmediciner.

Aktivisternas kunskap är hämtad från deras engagemang för anhöriga och nära vänner. Ofta handlar det också om dem själva. Berättelser om HIV/AIDS kan ha samma funktion som detta engagemang enligt redaktörerna för en antologi, Nobody Ever Said AIDS: Stories and Poems from Southern Africa, som kom ut i Sydafrika i fjol. I sin introduktion lånar de titeln till en av dikterna i antologin och skriver att litteraturen ger en möjlighet att "Cross Over from Solitude", att byta ut isolering mot en känsla av gemenskap.

Trots att HIV/AIDS är ett mycket omdebatterat och stort samhällsproblem i södra Afrika har det dröjt länge innan det blivit ett tema i litteraturen. Sydafrikanen Phaswane Mpe skrev romanen Welcome to Our Hillbrow (2001). Han dog i december 2004. Sindiwe Magona, som också medverkar i antologin har tidigare publicerat en novell "A State of Outrage" (1999), som behandlar HIV/AIDS. Så när som på dessa få undantag finns HIV/AIDS inte i den sydafrikanska litteraturen. Denna litterära tystnad är symptomatisk för en situation där skam och tystnad är den mest utbredda reaktionen också bland personer med hög utbildning och tillgång till ekonomiska resurser. Antologin Nobody Ever Said Aids är resultatet av ett medvetet arbete som tar sin utgångspunkt i en övertygelse om ordens makt och vikten av att ta upp kampen mot tystnaden. I introduktionen skriver Kylie Thomas och Meg Samuelsson:

Art allows us to enter into the worlds of others and sometimes even to recognize ourselves in those worlds. The power of words to transport us from isolation to a sense of community, even if only imaginary, is particularly important in a context where so many people are made to feel cast out - alone with illness, with loss, with grief. (11)

Antologin innehåller bidrag från etablerade författare som bl.a. Achmat Dangor, Ingrid de 
Kok, Rustum Kozain, Antjie Krog, Sindiwe Magona och Dambudzo Marechera, men också texter av hittills oetablerade författare. Dessa hittills opublicerade texter valdes ut av författaren Njabulo S. Ndebele, som i förordet till antologin varnar läsaren för att detta inte är en lätt bok att läsa: "it is filled with pain, with sorrow and with loss" (9). Men han avslutar med att konstatera att eftersom antologin är en första möjlighet för många nya författare att publicera sig kan den också beskrivas som "a book of hope" och "a book of new beginnings" (9).

Texterna i antologin behandlar olika teman. Bland dem kan nämnas frågan om kvinnors och flickors utsatthet på grund av maktrelationer mellan män och kvinnor. Hit hör också texter som handlar om förändrade attityder till maskulinitet. Ett annat tema är protesten mot förnekande och stigmatisering. Ett tredje centralt tema är sorgen, de anhörigas sätt att handskas med förlust och förbereda sig för en närståendes död.

\section{Kvinnors utsatthet}

I södra Afrika är HIV/AIDS en epidemi som drabbar heterosexuella. Det handlar ofta om kvinnor och barn som blir smittade på grund av att männen har flera sexuella relationer, en situation som kvinnorna får lov att finna sig i så länge de inte har ekonomiska och sociala möjligheter att vägra ha sex med män som bär på smittan. Prostituerade kvinnor har också en mycket utsatt ställning.

Leila Halls novell "Girls in the Rear-view Mirror" handlar om Luis, en ung man i Mozambique som arbetar som lastbilschaufför och som under sina resor inleder ett seriöst förhållande med en prostituerad. Texten fokuserar på de konflikter som mannen upplever i relation till sin familj eftersom han omges av manlighetsideal som ser besök hos prostituerade som en självklar rättighet.

He reminded himself that he had a wife and three daughters back in his village. But he'd already been away for nearly two weeks, journeying from his village on the very northern tip of Mozambique down to Maputo, and it would be at least another two before he got back. And all around him there were other men, most of them had wives too, enjoying themselves in the back seats of their trucks or in a room in the inn. It was just sex, he told himself, just sex. And he was a man, with a man's needs. For two weeks, the only other voices he'd heard were Filipe's and the other truck drivers' they happened to meet along the way. Nothing but men. Men's voices, men's company, men's laughter, men's jokes. (24)

Ironiskt nog ser Luis inte att de prostituerade egentligen utgör en förlängning av denna värld av manlighet utan beslutar sig för att fly ifrån den genom att köpa sex. Han väljer en kvinna, Jotinha, som han upplever har en avståndstagande attityd till livet som prostituerad, och inleder ett förhållande med henne där han besöker henne regelbundet under fyra år. Ett romantiskt förhållande mellan en prostituerad och en sexköpare med familj och barn beskrivet enbart från mannens perspektiv blir ofta problematiskt och icke trovärdigt. I Leila Halls berättelse försvinner "Pretty Woman"- syndromet snabbt genom den tragiska vändning som berättelsen tar. Jotinha försvinner plötsligt och när Luis slutligen återser henne ligger hon döende i ett litet rum. Hon ber att få träffa Luis men han står inte ut med att se henne sjuk och kör sin väg, något som han genast ångrar. När han återvänder i samband med nästa resa är Jotinha död. Det är först nu som Luis förstår vilken sjukdom Jotinha lidit av och också konsekvenserna för honom själv. Hennes försvinnande och det hemlighetsfulla kring hennes sjukdom och död placeras nu in i ett sammanhang av liknande händelser som Luis försökt förtränga - minnen av avmagrade ensamma, döende mänskor. Jotinha lämnar efter sig en son och här skulle man kunna man vänta sig en ny vändning av berättelsen. Den förtvivlade Luis kunde ta sig an sonen och gottgöra det som han upplever som sitt svek mot Jotinha. Men också denna möjlighet att placera in en lycklig vändning i en tragisk berättelse har Leila Hall valt bort genom att låta Luis försvinna med barnet inlindat i Jotinhas klänning och sedan återvända utan barnet. 
I nyare Sydafrikansk litteratur som behandlar våldtäkt leder våldtäkten ofta till graviditet och barnet som sedan föds kommer att symbolisera en form av hopp mitt i all hopplöshet. Leila Halls berättelse rör sig på ett mycket mer realistiskt plan där prostitution ses som ett maktförhållande mellan sexköpare och prostituerad och där den prostituerade och hennes barn slutligen är de som dör. Luis överväger att ta hem barnet till sin fru i byn men han kan inte föreställa sig hur det ska gå till. Det som berättelsen låter ana men lämnar öppet är möjligheten att Jotinhas öde bara är början på det som snart kommer att drabba alla andra personer i berättelsen.

I novellen "Baba's Gifts" av Jenny Robson och Nomthandazo Zondo har vi samma tema. Denna gång är mannen en s.k. migrant worker, d.v.s. en man som arbetar i en stadsmiljö, vanligtvis en gruvarbetare i Johannesburg, men vars familj bor på landsbygden. Denna arbetare lever alltså utan sin familj under långa perioder och har i vissa fall också en annan kvinna eller en ny familj i staden. Systemet med migrantarbetare är en kvarleva från apartheidtiden då städerna under en lång tid systematiskt definierades som "vita" och där man genom lagstiftning försökte förhindra svarta mänskor från att bosätta sig i städerna samtidigt som gruvdriften och alla former av service, särskilt städning och barntillsyn i privata hem, var helt och hållet beroende av den svarta befolkningens arbete.

I "Baba's Gifts" berättas historien om MaNdlovu som väntar hemma i byn på att hennes man ska komma hem från gruvorna. Barnen är förväntansfulla, de undrar vilka gåvor pappa ska ha med sig hem. MaNdlovu själv ser till att allt är i ordning men det som främst upptar hennes tankar är kondomerna hon fått av Nurse Margaret och den information som hon helst inte vill veta av:

"You all know what your husbands do when they are away! Even if you keep silent, still you know very well!"

That is what Nurse Margaret said at the clinic in town. Nurse Margaret with her big face that makes her look almost like a man. Nurse Margaret who says the most scandalous things and speaks about the most private affairs there in the clinic waiting-room. Sometimes MaNdlovu wants to cover her ears with her hands. Sometimes she wants to run out of the clinic so she won't hear.

"Yes, ladies! The time is past when these things must be kept secret. For your own sakes, for the sakes of your children, we must speak these things out loud." (99-100)

Berättelsen är uppbyggd kring MaNdlovus problem med att föra något så pinsamt och skamligt som könsorgan och kondomer på tal med sin man. Den kretsar kring föreställningen om att insikt borde leda till handling men vittnar samtidigt om en mycket komplicerad situation där kvinnors underordning inte behöver ta sig några spektakulära eller våldsamma uttryck. I MaNdlovus fall räcker det med att hennes man skrattar ut henne och Nurse Margarets kondomer. Hon vet att hon måste göra som han säger: "In the darkness, without her small square package of protection, MaNdlovu gets into bed beside her husband. He still smells of the city, despite his bath" (102). På samma sätt som i "Girls in the Rear-view Mirror" har vi ett slut som låter ana en framtida tragik.

I berättelserna som fokuserar på kvinnors utsatthet används ofta ett berättartekniskt grepp där mannens handlande förklaras genom hans upplevelser och hans kvinnosyn. Det här blir särskilt tydligt i novellen "Lady-killer", en titel som egentligen refererar till en attraktiv man som lätt förför kvinnor. Denna metaforiska innebörd blir snart bokstavlig när det visar sig att Roderick fortsätter med sitt liv som kvinnotjusare trots att han vet att han bär på HIV-smittan. Inför personalen på "the AIDS Welfare Centre", som beskrivs som "white liberals," talar han gärna om sin sorg över flickvännens död men nämner inte att det var han som genom sina sexuella eskapader blev smittad och inte brydde sig om att skydda henne. Samma attityd går igen när det gäller hans relationer till prostituerade. Han insisterar på att ha oskyddade samlag med dem och samtidigt är han förvånad över att de går med på detta krav, eftersom sjukdomen redan syns på hans utseende. Slutsatsen han 
drar är att de helt enkelt inte vet något om HIV/AIDS och därför inte kan skydda sig. "Lady-killer" är kanske den mest uttalat polariserade berättelsen i antologin: Roderick personifierar en livsstil bland män där oerfarna kvinnor utnyttjas, överges och dör medan männen fortsätter sina eskapader. Det finns inget tragiskt i Rodericks livsöde, däremot får vi veta att den prostituerade han vaknar upp bredvid en morgon, och som nu troligen också bär på smittan, blev tvingad in i prostitution på grund av att hon blev utnyttjad och övergiven av sin vita arbetsgivare i Harare. Novellen är skriven av Vivienne Ndlovu som ursprungligen kommer från Irland men som nu är bosatt i Zimbabwe. Hon har publicerat två romaner och "Lady-killer" är en adapterad och förkortad version av romanen Waste Not Your Tears.

\section{Protest mot förnekandet av HIV/AIDS}

Trots att prominenta personer i Sydafrika framträder och öppet talar om att deras nära anhöriga har avlidit i AIDS hör denna öppenhet fortfarande till undantagen. HIV/AIDS leder till isolering och stigmatisering. De flesta anhöriga väljer därför att inte tala om AIDS i familjen. I aktiviströrelser som Treatment Action Campaign finns en klar koppling till anti-apartheidtidens protestuttryck. Dikterna i antologin uppmanar till motstånd mot en regering som förnekar sjukdomen och som inte tillhandahåller bromsmediciner. Denna form av protestlyrik innebär en naturlig fortsättning på den koppling som alltid funnits mellan litteratur och politik i södra Afrika. Roshila Nairs "Fanon's Land" är tillägnad Zachie Achmat och andra aktivister inom Treatment Action Campaign. Genom att referera till den centrala postkoloniala teoretikern Frantz Fanon skapar dikten en koppling mellan kampen mot kolonialismen och den frustration som nu upplevs i Sydafrika inför fortsatt fattigdom och brist på sjukvårdsresurser.

here in Fanon's no-man's land we are beginning to learn how to make everything out of nothing again. (179)

I novellerna däremot behandlas tystnad och förnekande nästan uteslutande som en del av ett privat dilemma. På samma sätt som novellerna om kvinnors utsatthet är uppbyggda kring en klart uttalad norm där tragiken kan hänföras till vissa oreflekterade beteenden och skeva maktförhållanden är berättelserna om förnekande uppbyggda på dikotomin mellan tystnad och öppenhet. Här finns naturligtvis också ett ställningstagande för öppenheten men tystnaden och förnekandet beskrivs samtidigt på ett mycket intressant och mångfacetterat sätt.

Norah Mumba från Zambia beskriver i "The Fire Next Time" vänskapen mellan två kvinnor, Thokoza studerar i England och Zondiwe arbetar som sjuksköterska i ett oidentifierat afrikanskt land. Novellens titel är tagen från den amerikanske mänskorättsaktivisten James Baldwins essäsamling The Fire Next Time (1963) med följande epigram "God gave Noah the rainbow sign, No more water, the fire next time!" (50). Novellen citerar också Uppenbarelseboken och profeten Malaki med hänvisningar till Guds vrede. Medan Baldwins essä varnar för konsekvenserna av ett rasistiskt amerikanskt samhälle förblir det något oklart vad epigrammen syftar på i Mumbas novell. Är det tystnaden och bristen på engagemang inför AIDS-epidemin eller är det epidemin i sig som är ett straff från Gud?

Zondiwes arbete som sjuksköterska gör att hon tidigt kommer i kontakt med föräldralösa, AIDS-sjuka barn. Hon är en mycket erfaren person och insatt i HIV/AIDS-frågor och hon diskuterar också situationen med sina vänner och kolleger. När hennes arbetsgivare uppmanar alla anställda att låta HIV-testa sig gör hon detta först av alla för att föregå med gott exempel. Situationen förändras drastiskt när testet visar sig vara positivt. Zondiwe fortsätter brevväxlingen med Thokoza men nämner inte sjukdomen. I breven lever Zondiwe ett parallellt liv som en frisk mänska - i dem gör hon upp planer för framtiden tillsammans med Thokoza. Novellen slutar med det sista brevet hem: " I have successfully finished my 
studies and will be home at the end of next month. You are the one person I look forward to seeing the most when I arrive" (63). Men då har Thokoza redan avlidit. Genom att låta huvudpersonen skapa sig ett parallellt liv i brevväxlingen och med stor öppenhet diskutera olika problem kring HIV/AIDS med sin kusin men samtidigt hemlighålla sin egen status som HIV-positiv blir problemet kring tystnad och öppenhet mångfacetterat och komplicerat. Öppenhet och tolerans visar sig vara lättare att handskas med när det handlar om andras sjukdom.

Novellerna som problematiserar detta förnekande av den egna sjukdomen är också tydliga i sin kritik av "vanligt manligt beteende". I "The Fire Next Time" är det Thokozas man som plötsligt inser att det är han som dragit på sig smittan och gett den vidare till sin hustru: "He agonised over a couple of indiscretions committed at a time of great stress in his career, and even cast his mind back to the period before he met his wife. Indiscretions that to him were totally meaningless and had been quickly pushed to the back of his mind some wanton moments of excitement with faceless and nameless women" (61).

Khaya Gqibitoles "Fresh Scars" berättas i första person av en man som ser sin beundrade barndomsvän, Jola, återvända till byn, inte för en längre semester utan "home to die" - ett vanligt fenomen på landsbygden när det gäller aids-sjuka som inte får vård någon annanstans. Berättaren vet vad saken gäller eftersom han redan hört rykten om att Jolas fru plötsligt dragit sig tillbaka från allt socialt umgänge. Istället för att genast söka upp sin familj stannar Jola hos sin vän för att berätta om sin sjukdom för honom, något som berättaren inte gärna vill höra: "I could tell that he had come to the heart of the matter. I was torn. On the one hand I wanted to help my friend, while on the other I did not want to know what was troubling him so deeply. I always tell myself that bad news is like cancer. Once you hear it, it gets to you and devours you" (95). Berättelsen blir en bekännelse som utmynnar i en varning för konsekvenserna av mäns sexuella beteende. Trots att fokus ligger på förtroligheten mellan två män finns det inget i Jolas berättelse som urskuldar detta beteende. Det finns inga reflektioner över svarta mäns erfarenheter av förnedring under apartheidtiden eller av de våldsamma uppväxtvillkor som många unga män i kåkstäderna är utsatta för. Här handlar det om en man vars enda problem med sin hustru är att hon ännu inte har fött en son, men också det här visar sig vara en ursäkt snarare än en verklig orsak till hans beteende. I Jolas bekännelse inför sin vän säger han: "I must be honest with you. ... I did not cheat in order to get a son. I cheated because I had power, power to have any woman I fancied. Conquering women became my passion" (96). Tystnad och öppenhet blir igen två aspekter av samma berättelse. När det gäller tystnaden kring HIV/AIDS handlar det om att leva två parallella liv inför olika mänskor. I beskrivningen av mäns beteende och deras insikt om att de bär skulden till kvinnors död ser vi aldrig en situation där kvinnorna får höra en bekännelse eller öppet konfrontera männen.

I Sindiwe Magonas novell "Leave-taking" handlar tystnaden kring HIV/AIDS åter om en medelklassfamilj där frågan om hur en god hustru bör bete sig mot en otrogen man plötsligt får helt andra dimensioner. Sindiwe Magona är en etablerad författare som skrivit romaner, noveller och en självbiografi om sin uppväxt i en av Kapstadens kåkstäder. Novellen "Leave-taking" börjar med orden "God - I hate you!", uttalade av huvudpersonen Nontando på sin dotters begravning. Orden väcker stor uppmärksamhet och villrådighet i församlingen eftersom Nontando är en av dess viktigaste medlemmar. Det visar sig att Nontandos församlingstillhörighet liksom hennes liv i övrigt bygger på behovet av socialt anseende snarare än på någon verklig övertygelse. Samma behov har också dikterat hennes förhållande till dottern som levt ett olyckligt liv med sin inflytelserika men otrogna man. Nontando har sett det som sin viktigaste uppgift att övertala dottern att stanna hos mannen och nu ser hon honom som en mördare och sig själv som delaktig i dotterns mord. Hennes son har också insjuknat i aids men Nontando har lyckats bevara hemligheten så väl att inte ens hans syskon vet något.

Novellen riktar skarp kritik mot ett system där äldre kvinnor ser det som sin främsta uppgift att förhindra förändringar till det bättre för den yngre generationen. Nontando presenteras som en kvinna som är stolt över sitt sätt att underordna sig män och som bygger sitt sociala 
anseende på sin underordnade roll. Genom dotterns sjukdom ser hon plötsligt att hennes uppgift är att försöka förändra omgivningens syn på HIV/AIDS. Det motstånd som hon nu möter visar att hennes värderingar och hennes tystnad egentligen bara är ett gensvar på de förväntningar som ställts på henne. Novellen identifierar motståndet mot öppenhet på alla nivåer - från regeringen, kyrkan och församlingen till släktingar och familjemedlemmar. Här finns också en intressant diskussion om orsakerna till det utbredda motståndet mot att tala om sexuella relationer. Magona låter sin huvudperson identifiera övergångsriterna i det traditionella samhället som det sätt på vilket kunskap om sexualitet fördes vidare från en generation till en annan. När missionärerna kom förde de med sig en puritansk sexfientlighet som gjorde att möjligheterna att förmedla sexualkunskap till ungdomarna försvann. På samma sätt gör Magona Nontando till språkrör för den utbredda frustrationen bland HIV/AIDS-aktivister när det gäller president Thabo Mbekis sätt att handskas med pandemin: "Listen to the criminally ridiculous statements from the government! Poverty causes AIDS. Indeed! Then South Africa must be the poorest country on the face of the earth!" (134)

Också den här novellen kännetecknas av en tragisk grundton som poängterar att nya föresatser om en ändrad livsstil eller större öppenhet inte kan motverka medvetenheten om att sjukdomen alltid oundvikligt leder till döden. Det är sjukdom och död som står i berättelsernas centrum.

\section{Sorg och förlust}

Antologins dikter uttrycker sorg och förlust på ett något annat sätt än novellerna. De ger sig i kast med försöket att skapa ett språk för en erfarenhet som kanske enbart kan uttryckas genom tystnad. I Karen Press' "flakes of the light falling", en dikt som hon kallar "plague poem" , återkommer hon till uttrycket "metaphors of love crack open" i olika sammanhang. Det visar på den nya kontext som språket plötsligt befinner sig i när det ska beskriva en farsot med ännu oöverstigliga konsekvenser.

approximately and here also

one in four vanishing

even as we speak -

lightly and without technique they are dying

slowly and beyond the duration of love

good citizens of a good country, dying modestly

embrace of the infected is a national project

rejection the prerogative of the intimate circle (48)

Här uttrycks samma insikt som i novellen "The Fire Next Time" om hur tystnad och förnekande plötsligt inträder när sjukdomen blivit en del av familjen också bland personer som tidigare varit aktiva förespråkare för tolerans och öppenhet.

De överlevandes hjälplöshet uttrycks i stark kontrast till siffrornas logik:

approximately and here also

one in four vanishing -

how many little pallbearers for one coffin?

to wrap your father in a sheet takes days and days

tangling yourself in the web of bones

who will bury him if you don't?

you saw helplessly at the tree (48) 
Här blir det tydligt att vi har att göra med en helt ny form av farsot. Den starka, unga arbetsföra befolkningen dör ut och de svagaste, barnen och åldringarna, lämnas ensamma med alltför svåra uppgifter.

Ingrid de Koks "The Head of the Household" tar upp samma tema. Det är barnen som blir kvar och de har nu ansvar för ett helt hushåll.

The Head of the Household

is a girl of thirteen

and her children are many (169).

Inte heller den här dikten lämnar något utrymme för hopp. Den är formad kring insikten om det hopplösa i en trettonårings försök att ensam ansvara för sjuka och döende syskon.

Antologin avslutas med dikten "When I Rise" av Mthuthuzeli Isaac Skosana, en protestdikt skriven som en besvärjelse av en framtid utan HIV/AIDS. De tragedier som redan utspelat sig har ingen betydelse längre in den framtida utopin. Proteströrelsernas framväxt har skapat nya möjligheter att beskriva pandemin även i litterär form men det blir tydligt att det är vid stora evenemang som demonstrationer och officiella begravningar som dessa uttrycksformer växer fram och där de också får bäst resonans.

I en antologi av det här slaget är Rustum Kozains dikt "Crossing from Solitude" kanske den dikt som allra bäst skapar möjligheter till reflektion över stora och komplicerade frågor. I stark kontrast till novellerna, som beskriver sexuella relationer uteslutande som ytliga, farliga och förkastliga, skapar Rustum Kozain ett sammanhang med sexualiteten som en del av mänsklig kommunikation.

[...] A bath that cools for no one, an odd blue sky, the sun that falls now towards evening, towards winter

as our confessions deepen, declarations that circle and skirt the unsaid of how else the human might cross from solitude. (72)

Källa

Nobody Ever Said AIDS: Stories and Poems from Southern Africa. Eds. Nobantu Rasebotsa, Meg Samuelson and Kylie Thomas. Cape Town: Kwela Books, 2004.

\section{(C) Maria Olaussen}

